University of Nebraska - Lincoln

DigitalCommons@University of Nebraska - Lincoln

Agronomy \& Horticulture -- Faculty Publications

Agronomy and Horticulture Department

June 2000

\title{
Soil health and sustainability: managing the biotic component of soil quality
}

John W. Doran

University of Nebraska-Lincoln, jdoran1@unl.edu

Michael R. Zeiss

FAO IPM Programme

Follow this and additional works at: https://digitalcommons.unl.edu/agronomyfacpub

Part of the Plant Sciences Commons

Doran, John W. and Zeiss, Michael R., "Soil health and sustainability: managing the biotic component of soil quality" (2000). Agronomy \& Horticulture -- Faculty Publications. 15.

https://digitalcommons.unl.edu/agronomyfacpub/15

This Article is brought to you for free and open access by the Agronomy and Horticulture Department at DigitalCommons@University of Nebraska - Lincoln. It has been accepted for inclusion in Agronomy \& Horticulture -Faculty Publications by an authorized administrator of DigitalCommons@University of Nebraska - Lincoln. 


\title{
Applied Soil Ecology
}

ELSEVIER

Applied Soil Ecology 15 (2000) 3-11

www.elsevier.com/locate/apsoil

\section{Soil health and sustainability: managing the biotic component of soil quality}

\author{
John W. Doran ${ }^{\mathrm{a}, *}$, Michael R. Zeiss ${ }^{\mathrm{b}}$ \\ ${ }^{a}$ USDA-ARS, 116 Keim Hall, University of Nebraska, Lincoln, NE 68583, USA \\ ${ }^{\mathrm{b}}$ FAO IPM Programme, 3 Nguyen Gia Thieu, Hanoi, Viet Nam
}

\begin{abstract}
Soil health is the capacity of soil to function as a vital living system, within ecosystem and land-use boundaries, to sustain plant and animal productivity, maintain or enhance water and air quality, and promote plant and animal health. Anthropogenic reductions in soil health, and of individual components of soil quality, are a pressing ecological concern. A conference entitled 'Soil Health: Managing the Biological Component of Soil Quality' was held was held in the USA in November 1998 to help increase awareness of the importance and utility of soil organisms as indicators of soil quality and determinants of soil health. To evaluate sustainability of agricultural practices, assessment of soil health using various indicators of soil quality is needed. Soil organism and biotic parameters (e.g. abundance, diversity, food web structure, or community stability) meet most of the five criteria for useful indicators of soil quality. Soil organisms respond sensitively to land management practices and climate. They are well correlated with beneficial soil and ecosystem functions including water storage, decomposition and nutrient cycling, detoxification of toxicants, and suppression of noxious and pathogenic organisms. Soil organisms also illustrate the chain of cause and effect that links land management decisions to ultimate productivity and health of plants and animals. Indicators must be comprehensible and useful to land managers, who are the ultimate stewards of soil quality and soil health. Visible organisms such as earthworms, insects, and molds have historically met this criterion. Finally, indicators must be easy and inexpensive to measure, but the need for knowledge of taxonomy complicates the measurement of soil organisms. Several farmer-participatory programs for managing soil quality and health have incorporated abiotic and simple biotic indicators. The challenge for the future is to develop sustainable management systems which are the vanguard of soil health; soil quality indicators are merely a means towards this end. Published by Elsevier Science B.V.
\end{abstract}

Keywords: Soil health; Soil quality; Ecosystem functions

\section{Introduction}

Interest in evaluating the quality and health of our soil resources has been stimulated by increasing awareness that soil is a critically important component of the earth's biosphere, functioning not only in the production of food and fiber but also in the

\footnotetext{
* Corresponding author. Tel.: +1-402-472-1510; fax: +1-402-472-0516.

E-mail address: jdoran1@unl.edu (J.W. Doran)
}

maintenance of local, regional, and global environmental quality (Glanz, 1995). Soil is also the basis of agricultural and of natural plant communities. Thus, the thin layer of soil covering the surface of the earth represents the difference between survival and extinction for most land-based life (Doran et al., 1996). However, inventories of soil productive capacity indicate human-induced degradation on nearly $40 \%$ of the world's agricultural land as a result of soil erosion, atmospheric pollution, extensive soil cultivation, over-grazing, land clearing, salinization, and 
desertification (Oldeman, 1994). Indeed, degradation and loss of productive agricultural land is one of our most pressing ecological concerns, rivaled only by human caused environmental problems like global climate change, depletion of the protective ozone layer, and serious declines in biodiversity (Lal, 1998).

Soil quality has been defined by the Soil Science Society of America Ad Hoc Committee on soil quality (S-581) as 'the capacity of a specific kind of soil to function, within natural or managed ecosystem boundaries, to sustain plant and animal productivity, maintain or enhance water and air quality, and support human health and habitation' (Karlen et al., 1997). In discussion of the ambiguity of environmental terms and the need to standardize their meanings, Johnson et al. (1997) defined soil quality as 'a measure of the condition of soil relative to the requirements of one or more biological species and/or to any human purpose'. The term 'soil health' is preferred by some (for a discussion see Doran et al., 1996; Doran and Safley, 1997) because it portrays soil as a living, dynamic system whose functions are mediated by a diversity of living organisms that require management and conservation. Soil health, biodiversity, and soil resilience are severely limited in extreme environments and are more sensitive to anthropogenic disturbance (Freckman and Virginia, 1997). The terms soil quality and soil health will be used synonymously throughout this paper. However use of the term soil quality will generally be associated with a soils' fitness for a specific use and the term soil health used in a broader sense to indicate the capacity of soil to function as a vital living system to sustain biological productivity, promote environmental quality, and maintain plant and animal health. In this sense soil health is synonymous with sustainability. The quality of a soil includes an inherent component, determined by the soil's physical and chemical properties within the constraints set by climate and ecosystem. In addition, soil quality includes a component affected by management and land-use decisions. Unfortunately, past management of agriculture and other ecosystems has substantially degraded and reduced the quality of many soils throughout the world (Saunders, 1992; Oldeman, 1994). In particular, mechanical cultivation and the continuous production of row crops has resulted in physical loss of soil, displacement through erosion, and large decreases in soil organic matter content with a concomitant release of
$\mathrm{CO}_{2}$ to the atmosphere (Houghton et al., 1983). Further, the projected doubling of the human population in the next century threatens accelerated degradation of soils and other natural resources (Power, 1996). Thus, to preserve agriculture for future generations, we must develop production systems that conserve and enhance soil quality.

As a small step towards this end, a conference entitled 'Soil Health: Managing the Biological Component of Soil Quality' was held as part of the joint annual meeting of the Entomological Society of America (ESA) and the American Phytopathology Society (APS) which convened in Las Vegas, Nevada in November 1998. The goals of the conference were to increase awareness within the ESA and APS of the utility of soil organisms as indicators of soil quality, and to permit researchers from diverse disciplines to integrate results from multiple taxa of soil organisms. The overarching objective was to help 'translate science into practice' by providing a forum for researchers and extension workers to discuss farmer-participatory programs for managing soil quality. The papers published in this issue were presented in abbreviated form during the conference.

\section{Soil quality: indicator of sustainable land management}

Developing sustainable land management systems is complicated by the need to consider their utility to humans, their efficiency of resource use, and their ability to maintain a balance with the environment that is favorable both to humans and most other species (Harwood, 1990). In particular, we are challenged to develop agricultural management systems that balance the needs for production of food and fiber with those for maintenance of the environment. More simply stated by Tom Franzen, a midwestern farmer in the USA, "a sustainable agriculture - sustains the people and preserves the land." Soil quality is conceptualized as the major linkage between the strategies for agricultural conservation management practices and achievement of the major goals of sustainable agriculture (Parr et al., 1992; Acton and Gregorich, 1995). In short, the assessment of soil quality or health, and direction of change with time, is the primary indicator of sustainable land management (Karlen et al., 1997). 
Although soil's contribution to plant productivity is widely recognized, soil condition also impacts water and air quality. The quality of surface and sub-surface water has been jeopardized in many parts of the world by intensive land management practices and the consequent imbalance of $\mathrm{C}, \mathrm{N}$, and water cycling in soil. Agriculture is considered the most widespread contributor to nonpoint source water pollution in the USA (National Research Council, 1993). The major water contaminant in North America and Europe is nitrate nitrogen, the principal sources of which are conversion of unmanaged land to intensive agriculture, animal manures, atmospheric deposition, and commercial fertilizers. Human alterations of the nitrogen cycle have almost doubled the rate of nitrogen input to terrestrial ecosystems over the past 30 years resulting in large increases in the transfer of nitrogen from land to the atmosphere and to rivers, estuarines, and coastal oceans (Vitousek et al., 1997). Soil management practices such as tillage, cropping patterns, and pesticide and fertilizer use influence water quality. In addition, these management practices can influence atmospheric quality through changes in the soil's capacity to produce or consume important atmospheric gases such as carbon dioxide, nitrous oxide, and methane (Rolston et al., 1993; Mosier, 1998). The present threat of global climate change and ozone depletion, through elevated levels of greenhouse gases and altered hydrological cycles, necessitates a better understanding of the influence of land management on soil processes (Bengtsson, 1998). In summary, the quality and health of soil determine agricultural sustainability (Papendick and Parr, 1992; Acton and Gregorich, 1995), environmental quality (Pierzynski et al., 1994), and as a consequence of both, plant, animal, and human health (Haberern, 1992; Harris et al., 1996).

Scientists make a significant contribution to sustainable land management by translating scientific knowledge and information on soil function into practical tools and approaches by which land managers can assess the sustainability of their management practices (Dumanski et al., 1992; Bouma, 1997). Specifically, assessment of soil quality/health is needed to identify problem production areas, make realistic estimates of food production, monitor changes in sustainability and environmental quality as related to agricultural management, and to assist government agencies in formulating and evaluating sustainable agricultural and land-use policies (Granatstein and Bezdicek, 1992). Use of one given approach for assessing or indexing soil quality is fraught with complexity and precludes its practical or meaningful use by land managers or policy makers (Harris et al., 1996). However, the use of simple indicators of soil quality and health which have meaning to farmers and other land managers will likely be the most fruitful means of linking science with practice in assessing the sustainability of management practices (Romig et al., 1995, 1996).

\section{Use of soil organisms as indicators of soil quality and health}

Criteria for indicators of soil quality and health relate mainly to their utility in defining ecosystem processes and integrating physical, chemical, and biological properties, their sensitivity to management and climatic variations, and their accessibility and utility to agricultural specialists, producers, conservationists, and policy makers (Doran and Parkin, 1996). As discussed below, measurements of soil organisms meet many (though not all) of the criteria for useful indicators of sustainable land management. For this reason, soil organisms (including their abundance, diversity, food web structure, and community stability; see Brussaard et al., 1997) were the focus of the conference published in this issue. Most of the subsequent papers in this issue address the questions of which of the presently known organisms and ecological parameters are most useful as indicators. But any indicator of soil health or soil quality should meet the following five criteria.

\subsection{Sensitivity to variations in management}

To be useful as an indicator of the sustainability of land management practices, a soil parameter must respond to changes in management sensitively. Specifically, 'the indicators should be sensitive enough to reflect the influence of management and climate on long-term changes in soil quality but not be so sensitive as to be influenced by short-term weather patterns' (Doran and Parkin, 1996). Soil organisms meet this criterion, because they respond sensitively to anthropogenic disturbance (Pankhurst et al., 1997; Wolters and Schaefer, 1994). Numerous additional 
examples can be found in Appl. Soil Ecol. 9 (1998) 306-428, which is a special issue dedicated to 'Soil Organisms and Soil Resource Management'. Further, both Rosemeyer and Abawi (this issue) present management-induced changes in abundance and diversity of bacteria, fungi, and nematodes.

\subsection{Well correlated with beneficial soil functions}

Soil health is worth quantifying because soils and their biota provide ecosystems functions that benefit humans. These ecosystem services can be of considerable value (Costanza et al., 1997) and include soil functions of storing and releasing water, decomposing plant and animal residues, transforming and recycling nutrients, sequestering and detoxifying organic toxicants, and promoting plant health by suppressing plant-pathogenic microbes and phytophagous fauna. It is often possible and desirable to measure soil function directly. For example, in participatory research with US farmers, decomposition rate was directly measured by periodically examining samples of buried paper (Drinkwater and Wander, this issue). In contrast, direct measurements of some soil functions may be too expensive (for example, direct measurements of nutrient transformations) or require observations across too much time (for example, the capacity of a soil to supply water for plant growth during a drought may be observable only during rare drought years). In such cases, rather than measuring the soil function directly, it may be preferable to measure surrogates or proxies that are well correlated with the soil function. Soil organisms meet this criterion, because the abundance and diversity of soil organisms often are well correlated with many beneficial soil functions (Pankhurst et al., 1997). However, care is needed in selecting which organism or which community parameter to use as a proxy for soil function (Bengtsson, 1998).

\subsection{Useful for elucidating ecosystem processes}

To aid farmers, ranchers, conservationists, foresters, and other land managers in selecting appropriate interventions, an indicator of soil quality must do more than merely predicting whether a soil will provide a beneficial function (Section 3.2). The indicator should also elucidate why the soil will or will not function as desired. For example, plant productivity and health are invaluable indicators because they are well correlated with multiple soil functions (Anderson, 1988; Doran et al., 1996). Nonetheless, if plant productivity or health are measured and found to be lower than desired, it is not obvious what remedial action is required. Therefore, indicators are needed that help land managers understand the chain of cause and effect that links land management decisions to ultimate productivity and health of plants and animals. Soil organisms meet this criterion, because they play a direct role in many ecosystem processes including conversion of nutrients into forms available to plants (Anderson, 1988; Drinkwater et al., 1996) and suppression of noxious organisms (Bongers and Bongers, 1998; Oyarzun et al., 1998). Further, by affecting soil structure, soil organisms play a critical indirect role in processes such as water infiltration (Anderson, 1995).

\subsection{Comprehensible and useful to land managers}

The ultimate determinant of soil quality and health is the farm owner or operator, rancher, forester, golf course superintendant, conservationists, etc. who actually manage the land. Thus, the land manager is the ultimate judge of which indicators of soil quality are worth measuring. Considerable thought and creativity are required to develop measurements of soil organisms that are comprehensible and useful to land managers. Both in the US (Drinkwater and Wander, this issue) and Ecuador (Carroll et al., this issue), farmer-participatory programs for promoting soil health have successfully included earthworm abundance as an indicator. In addition, measurements of the abundance and diversity of nematodes (Bongers and Bongers, 1998), mites (Behan-Pelletier, this issue) and bacteria (Nelson and van Bruggen, this issue) could provide a wealth of information on soil functions and processes but likely requires too much specialized training for land managers. It remains an open question whether these potentially valuable biological indicators can be made accessible to land managers.

\subsection{Easy and inexpensive to measure}

Because the ultimate determinant of soil quality and health is the land manager, indicators of soil quality and sustainability should be both accessible to them and economic in terms of both time and 
money. This argues against the use of species richness ('biodiversity') as an indicator, because quantifying species richness requires substantial knowledge of taxonomy and can be extremely time consuming and costly. However, it may be possible to develop measures of functional diversity measurable by non-taxonomists (Bengtsson, 1998). In general, quantifying soil organisms neither is inherently expensive nor requires much specialized equipment (e.g. Blair et al., 1996; Pankhurst et al., 1997). However, research is needed to develop sampling protocols (Dick et al., 1996) compatible with the time constraints imposed by the normally hectic and unpredictable schedules of land managers.

In summary, measurements of soil organisms are sensitive to anthropogenic perturbations, are well correlated with beneficial soil functions, and are excellent teaching tools because they elucidate ecosystem processes. However, it is a challenge to develop measurements of soil organisms that are meaningful to land managers, and that can be quantified within the time and skills available to land managers. Thus, as for any indicator, the utility of quantifying soil organisms as part of a program for promoting soil quality and health will depend on the objectives of the specific program.

\section{Translating science into practice}

In the US, the Soil Science Society of America has taken a lead role in defining and promoting soil quality and health. As a step towards defining sustainable agricultural management practices, Doran et al. (1994a) stressed the importance of holistic management approaches that optimize the multiple functions of soil, conserve soil resources, and support strategies for promoting soil quality and health. They initially proposed use of a basic set of indicators to assess soil quality and health in various agricultural management systems. However, while many of these key indicators are extremely useful to specialists (i.e. researchers, consultants, extension staff, and conservationists), many of them are beyond the expertise of the producer to measure (Hamblin, 1991). Also, the mere measurement of soil quality and health does nothing to improve the sustainability of the system under which the soil is managed. In response to this dilemma, Doran et al. (1996) presented strategies for ensuring sustainable management that included corresponding indicators of soil quality and health that are measurable by and accessible to producers (Table 1). Note that soil organic matter serves as a primary indicator of soil quality and health for both scientists and farmers (Romig et al., 1995).

Strategies for sustainable management, such as those shown in Table 1, maximize the benefits of natural cycles, reduce dependence on non-renewable resources, and help producers identify long-term goals for sustainability that also meet short-term needs for production. However, successful development and implementation of standards for assessment of soil health and sustainability can only be accomplished in partnership with agricultural producers, who are the primary stewards of the land. Economic survival and viability are the primary goals of land managers, and while most appreciate the need for environmental conservation, the simple fact remains that "it's hard to be green when you're in the red" (Ann Hamblin, Ballarat, Australia, April 1996).

Although much remains to be done, useful models exist for translating soil science into practice. For example, Gomez et al. (1996) provide a unique framework for determining the sustainability of hill country agriculture in the Philippines. It employs indicators that consider both the satisfaction of farmer needs (i.e. productivity, profitability, stability, and viability) and those needed for conservation of soil and water resources. On a given farm, indicators were deemed to be at a sustainable level if they exceeded a designated threshold level. Specifically, the threshold values for sustainability were identified relative to the average local conditions for crop yield, profit, risk of crop failure, soil depth, percent soil cover, and soil organic matter content. This conceptual framework for assessment of sustainability could be expanded to include other needs of society and environmental conservation as illustrated in Table 2. In particular, adding a category for balancing input and output of energy and monetary costs would better assess the short and long-term sustainability of management and the value of greater reliance on renewable resources in enhancing ecological and environmental resources. Also, expanding the list of resource conservation variables to include leachable salts (especially $\mathrm{NO}_{3}$ ), measured as soil electrical conductivity at time of fertilization and after harvest, would permit land managers to better quantify the 
Table 1

Strategies for sustainable agricultural management and proposed indicators of crop performance and soil and environmental health ${ }^{\mathrm{a}}$

\begin{tabular}{|c|c|}
\hline Sustainability strategy & Indicators for producers \\
\hline $\begin{array}{l}\text { Conserve soil organic matter through } \\
\text { Maintaining soil } \mathrm{C} \& \mathrm{~N} \text { levels by reducing tillage } \\
\text { Recycling plant and animal manures } \\
\text { And/or increasing plant diversity, } \\
\text { where C inputs } \geq \mathrm{C} \text { outputs }\end{array}$ & $\begin{array}{l}\text { Direction/change in organic matter levels with time (visual } \\
\text { or remote sensing by color or chemical analysis) } \\
\text { Specific OM potential for climate, soil, and vegetation } \\
\text { Soil water storage }\end{array}$ \\
\hline $\begin{array}{l}\text { Minimize soil erosion through } \\
\text { Conservation tillage } \\
\text { Increased protective cover (residue, } \\
\text { stable aggregates, cover crops, green fallow) }\end{array}$ & $\begin{array}{l}\text { Visual (gullies, rills, dust, etc.) } \\
\text { Surface soil properties (topsoil depth, organic matter } \\
\text { content/texture, water infiltration, runoff, ponding, cover \%) }\end{array}$ \\
\hline $\begin{array}{l}\text { Balance production and environment through } \\
\text { Conservation and integrated management systems } \\
\text { (optimizing tillage, residue, water, and chemical use) } \\
\text { Synchronizing available N and P levels with crop needs } \\
\text { during year }\end{array}$ & $\begin{array}{l}\text { Crop characteristics (visual or remote sensing of yield, color, } \\
\text { nutrient status, plant vigor, and rooting characteristics) Soil } \\
\text { physical condition/compaction } \\
\text { Soil and water nitrate levels } \\
\text { Amount and toxicity of pesticides used }\end{array}$ \\
\hline $\begin{array}{l}\text { Better use of renewable resources through } \\
\text { Relying less on fossil fuels and petrochemicals } \\
\text { More on renewable resources and biodiversity } \\
\text { (crop rotations, legumes, manures, IPM, etc.) }\end{array}$ & $\begin{array}{l}\text { Input/output ratios of costs, energy, and } \\
\text { renewable/non-renewable resources } \\
\text { Leaching losses/soil acidification } \\
\text { Crop characteristics (as listed above) } \\
\text { Soil and water nitrate levels }\end{array}$ \\
\hline
\end{tabular}

${ }^{a}$ Modified from Doran et al. (1996).

impact of agricultural practices on water quality (Doran, 1997; Doran et al., 1998). In addition, Carroll et al. (this issue) and Drinkwater and Wander (this issue) provide other examples of successful, participatory programs to quantify and enhance soil quality.

The theme of a recent conference in Australia, 'Soil quality is in the hands of the land manager' (Advances in Soil Quality: Science, Practice, and Policy, University of Ballarat, April 1996), should serve as the watchword for future efforts. A cotton grower at this conference expressed his frustration with the direction that the soil quality indicators proposed by researchers were taking: "I need help from scientists more with tools for management than with indicators of soil quality". The authors share the cotton grower's belief that the true goal is sustainable management of agricultural systems. Soil quality indicators in general, and biological indicators in particular, are merely a means towards that end.

\section{Resources for future work on soil health}

A partial listing of groups and published resources on soil quality and health as related to sustainable management are included here. Canadian contributions, which were among the first to be active in this area, are well reflected in the two publications (see

Table 2

Template of proposed indicators for measuring the sustainability of agricultural systems at the farm level ${ }^{\mathrm{a}}$

\begin{tabular}{ll}
\hline Farmer/society needs (acceptable) & Resource/environmental conservation (adequate/acceptable) \\
\hline Yields & Soil organic matter \\
Profits & Topsoil depth \\
Risk/stability & Soil protective cover $(\%)$ \\
Input/output ratio (energy and costs) & Leachable salts $\left(\mathrm{NO}_{3}\right)$ (soil electrical conductivity) \\
\hline
\end{tabular}

${ }^{\text {a }}$ Taken from Gomez et al. (1996). 
Acton and Gregorich, 1995; Gregorich and Carter, 1997). In the USA, the Soil Science Society of America has a soil quality working group within Division S-3 (Soil Biology and Biochemistry) which includes over 100 members from the US and other countries. This group was a major supporter of two important references on soil quality (see Doran et al., 1994b; Blair et al., 1996; Dick et al., 1996; Doran and Parkin, 1996; Drinkwater et al., 1996; Gomez et al., 1996; Harris et al., 1996; Romig et al., 1996). The home page address for the S-3 Soil Quality Working Group is (http://www.oznet.ksu.edu/pr_s3sm/soilqlty/) where a membership list, meeting minutes, seminars and events, and links to other groups such as the Bioremediation and Instruction Working Groups, the USDA-NRCS Soil Quality Institute, and the International Soil Quality Network can be found.

Other emphases on soil health and soil organisms have come from Doran et al. (1994a), Pankhurst et al. (1997), Soil Ecology Society, and the soil ecology section of the Ecological Society of America. Also worthy of recognition are the international efforts of individual scientists in the GCTE (Global Change and Terrestrial Ecology) and the Scientific Committee on Problems of the Environment (SCOPE) for which several workshops have recently identified a number of gaps in belowsurface knowledge (see http://www.nrel.colostate. edu/soil/scope.html). A Soil Biodiversity and Ecosystem Functioning page is also available at the Natural Resources Ecology Lab in Fort Collins, Colorado (see http://www.nrel.colostate. edu/soil/home.html).

The National Academy of Sciences has just approved a US National Committee on Soil Science, which raises the visibility of soils in international arenas. This committee will now represent soil biologists and other soil scientists in contributing to international decisions on biodiversity loss, invasive species and global change, particularly in major scientific contributors to international policy on global sustainability such as the International Congress of Scientific Unions (ICSU) (Personal communication from Diana Wall, Director of the Natural Resource Ecology Lab, 20 October 1998). The International Standardisation Organisation (ISO) established in 1985, a Technical Committee (ISO/TC 190) to consider the development of methodologies for monitoring the quality of soil. The scope of this Technical Committee and its work program are outlined by Hortensius and Nortcliff
(1991). Further details can be obtained by contacting Dr. Richard Wellings (Secretary, ISO/TC 190, NNI, P.O. Box 5059, 2600 GT Delft, The Netherlands; fax: +31-15-2690-190).

Summary findings of an international workshop on 'Soil health as an indicator of sustainable land management' which was held on 24-25 June 1999 in Athens, Greece, are reported by Doran and Stamatiadis (1999). The proceedings of this workshop are presently scheduled for publication as a special issue of Agriculture, Ecosystems and Environment in 2001.

\section{Acknowledgements}

Special thanks to George Abawi, co-organizer of the ESA/APS soil health conference, for his enthusiasm and logistical support. We gratefully acknowledge the Soil Quality Institute (of the US Department of Agriculture's Natural Resources Conservation Service) and the Henry A. Wallace Institute for Alternative Agriculture for their financial support of the conference. Thanks also to Doug Kleine (of the ESA) and Mary Barbercheck (chair of the Program Committee for the annual meeting) for their assiduous administrative efforts in support of the conference. Finally, our sincere thanks to all the conference participants for contributing their knowledge, time, and resources.

\section{References}

Acton, D.F., Gregorich, L.J., 1995. The Health of Our Soils: Toward Sustainable Agriculture in Canada. Agriculture Agri-Food Canada, CDR Unit, Ottawa.

Anderson, J., 1995. Soil organisms as engineers: microsite modulation of macroscale processes. In: Jones, C.G., Lawton, J.H. (Eds.), Linking Species and Ecosystems. Chapman \& Hall, London, pp. 94-106.

Anderson, J.M., 1988. The role of soil fauna in agricultural systems. In: Wilon, J.R. (Ed.), Advances in Nitrogen Cycling in Agricultural Ecosystems. CAB International, Wallingford, pp. 89-113.

Bengtsson, J., 1998. Which species? What kind of diversity? Which ecosystem function? Some problems in studies of relations between biodiversity and ecosystem function. Appl. Soil. Ecol. 10, 191-199.

Blair, J.M., Bohlen, P.J., Freckman, D.W., 1996. Soil invertebrates as indicators of soil quality. In: Doran, J.W., Jones, A.J. (Eds.), Methods for Assessing Soil Quality. Soil Science Society of America, Special Publication 49, Madison, WI, pp. 273-291. 
Bongers, T., Bongers, M., 1998. Functional diversity of nematodes. Appl. Soil Ecol. 10, 239-252.

Bouma, J., 1997. Soil environmental quality: a European perspective. J. Environ. Qual. 26, 26-31.

Brussaard et al., 1997. Biodiversity and ecosystem functioning in soil. Ambio 26, 563-570.

Costanza, R., d'Arge, R., de Groot, R., Farber, S., Grasso, M., Hannon, B., Limburg, K., Naeem, S., O'Neill, R.V., Paruelo, J., Raskin, R.G., Sutton, P., van den Belt, M., 1997. The value of the world's ecosystem services and natural capital. Nature 387, 253-259.

Dick, R.P., Thomas, D.R., Halvorson, J.J., 1996. Standardized methods, sampling, and sample pretreatment. In: Doran, J.W., Jones, A.J. (Eds.), Methods for Assessing Soil Quality. Soil Science Society of America, Special Publication 49, Madison, WI, pp. 107-121.

Doran, J.W., 1997. Soil quality and sustainability. In: Proceedings of the XXVI Brazilian Congress of Soil Science, Rio de Janeiro, Brazil, 20-26 July 1997.

Doran, J.W., Parkin, T.B., 1996. Quantitative indicators of soil quality: a minimum data set. In: Doran, J.W., Jones, A.J. (Eds.), Methods for Assessing Soil Quality. Soil Science Society of America, Special Publication 49, Madison, WI, pp. 25-37.

Doran, J.W., Safley, M., 1997. Defining and assessing soil health and sustainable productivity. In: Pankhurst, C., Doube, B.M., Gupta, V.V.S.R. (Eds.), Biological Indicators of Soil Health. CAB International, Wallingford, Oxon, UK, pp. 1-28.

Doran, J.W., Stamatiadis, S. 1999. Soil health as an Indicator of Sustainable Land Management: Summary Findings of an International Workshop. Agronomy Abstracts, Salt Lake City, Utah meeting, 31 October-4 November 1999.

Doran, J.W., Liebig, M.A., Santana, D.P., 1998. Soil health and global sustainability. In: Transactions of the 16th World Congress of Soil Science. Montepellier, France, 20-26 August 1998.

Doran, J.W., Sarrantonio, M., Janke, R., 1994a. Strategies to promote soil quality and soil health. In: Pankhurst, C.E., Doube, B.M., Gupta, V.V.S.R., Grace, P.R. (Eds.), Soil Biota: Management in Sustainable Farming Systems. CSIRO, Victoria, Australia, pp. 230-237.

Doran, J.W., Coleman, D.C., Bezdicek, D.F., Stewart, B.A. (Eds.), 1994b. Defining Soil Quality for a Sustainable Environment. Soil Science Society of America, Special Publication 35, Madison, WI.

Doran, J.W., Sarrantonio, M., Liebig, M., 1996. Soil health and sustainability. In: Sparks, D.L. (Ed.), Advances in Agronomy, Vol. 56. Academic Press, San Diego, pp. 1-54.

Drinkwater, L.E., Cambardella, C.A., Reeder, J.D., Rice, C.W., 1996. Potentially mineralizable nitrogen as an indicator of biologically active soil nitrogen. In: Doran, J.W., Jones, A.J. (Eds.), Methods for Assessing Soil Quality. Soil Science Society of America, Special Publication 49, Madison, WI, pp. 217-229.

Dumanski, J., Eswaran, H., Latham, M., 1992. A proposal for an international framework for evaluating sustainable land management. In: Evaluation for Sustainable Land Management in the Developing World. Vol. 2: Technical Papers. International Board for Soil Research and Management, Bangkok, Thailand, 1991. IBSRAM Proceeding No. 12 (2).
Freckman, D.W., Virginia, R.A., 1997. Low-diversity Antarctic soil nematode communities: distribution and response to disturbance. Ecology 78, 363-369.

Glanz, J.T., 1995. Saving Our Soil: Solutions for Sustaining Earth's Vital Resource. Johnson Books, Boulder, CO, USA.

Gomez, A.A., Swete Kelly, D.E., Seyers, J.K., Coughlan, K.J., 1996. Measuring sustainability of agricultural systems at the farm level. In: Doran, J.W., Jones, A.J. (Eds.), Methods for Assessing Soil Quality. Soil Science Society of America, Special Publication 49, Madison, WI, pp. 401-410.

Granatstein, D., Bezdicek, D.F., 1992. The need for a soil quality index: local and regional perspectives. Am. J. Altern. Agric. 7, 12-16.

Gregorich, E.G., Carter, M.R. (Eds.), 1997. Soil Quality for Crop Production and Ecosystem Health. Developments in Soil Science 25, Elsevier, Amsterdam.

Haberern, J., 1992. Viewpoint: a soil health index. J. Soil Water Conserv. 47, 6.

Hamblin, A., 1991. Environmental indicators for sustainable agriculture. Report of a national workshop. Publ. LWRRDC and GRDC, 96 pp.

Harris, R.F., Karlen, D.L., Mulla, D.J., 1996. A conceptual framework for assessment and management of soil quality and health. In: Doran, J.W., Jones, A.J. (Eds.), Methods for Assessing Soil Quality. Soil Science Society of America, Special Publication 49, Madison, WI, pp. 61-82.

Harwood, R.R., 1990. A history of sustainable agriculture. In: Edwards, C.A., Lal, R., Madden, P., Miller, R.H., House, G. (Eds.), Sustainable Agricultural Systems. Soil and Water Conservation Society, Ankeny, Iowa, USA, pp. 3-19.

Hortensius, D., Nortcliff, S., 1991. International standardization of soil quality measurement procedures for the purpose of soil protection. Soil Use Manage. 7, 163-166.

Houghton, R.A., Hobbie, J.E., Melillo, J.M., Moore, B., Peterson, B.J., Shaver, G.R., Woodwell, G.M., 1983. Changes in the carbon content of terrestrial biota and soils between 1860 and 1980: a net release of $\mathrm{CO}_{2}$ to the atmosphere. Ecol. Monog. 53, 235-262.

Johnson, D.L., Ambrose, S.H., Bassett, T.J., Bowen, M.L., Crummey, D.E., Isaacson, J.S., Johnson, D.N., Lamb, P., Saul, M., Winter-Nelson, A.E., 1997. Meanings of environmental terms. J. Environ. Qual. 26, 581-589.

Karlen, D.L., Mausbach, M.J., Doran, J.W., Cline, R.G., Harris, R.F., Schuman, G.E., 1997. Soil quality: a concept, definition, and framework for evaluation. Soil Sci. Soc. Am. J. 61, 4-10.

Lal, R., 1998. Basic concepts and global issues: soil quality and agricultural sustainability. In: Lal, R (Ed.), Soil Quality and Agricultural Sustainability. Ann Arbor Science, Chelsea, MI, USA, pp. 3-12.

Mosier, A.R., 1998. Soil processes and global change. Biol. Fertil. Soils 27, 221-229.

National Research Council, 1993. Soil and Water Quality: An Agenda for Agriculture. Committee on Long-Range Soil and Water Conservation, Board of Agriculture, National Research Council. National Academy Press, Washington, DC.

Oldeman, L.R., 1994. The global extent of soil degradation. In: Greenland, D.J., Szabolcs, I. (Eds.), Soil Resilience and 
Sustainable Land Use. CAB International, Wallingford, Oxon, UK, pp. 99-118.

Oyarzun, P.J., Gerlagh, M., Zadoks, J.C., 1998. Factors associated with soil receptivity to some fungal root rot pathogens of peas. Appl. Soil Ecol. 10, 151-169.

Pankhurst, C., Doube, B.M., Gupta, V.V.S.R. (Eds.), 1997. Biological Indicators of Soil Health. CAB International, Wallingford.

Papendick, R.I., Parr, J., 1992. Soil quality - the key to a sustainable agriculture. Am. J. Altern. Agric. 7, 2-3.

Parr, J.F., Papendick, R.I., Hornick, S.B., Meyer, R.E., 1992. Soil quality: attributes and relationship to alternative and sustainable agriculture. Am. J. Altern. Agric. 7, 5-11.

Pierzynski, G.M., Sims, J.T., Vance, G., 1994. Soils and Environmental Quality. Lewis Publishers, CRC Press, Boca Raton, FL, USA.

Power, J.F. 1996. Requirements for a sustainable agriculture for the next generation. In: Nath, B., Lang, I., Mesaros, E., Robinson, J.P., Hens, L. (Eds.), Proceedings of the International Conference on Environmental Pollution, Vol. 1, Budapest, Hungary, 15-19 April 1996. European Centre for Pollution Research, University of London, London, UK, pp. 92-98.
Rolston, D.E., Harper, L.A., Mosier, A.R., Duxbury, J.M., 1993. Agricultural Ecosystem Effects on Trace Gases and Global Climate Change. American Society of Agronomy, Special Publication 55, Madison, WI, USA.

Romig, D.E., Garlynd, M.J., Harris, R.F., 1996. Farmer-based assessment of soil quality: A soil health scorecard. In: Doran, J.W., Jones, A.J. (Eds.), Methods for Assessing Soil Quality. Soil Science Society of America, Special Publication 49, Madison, WI, pp. 39-60.

Romig, D.E., Garlynd, M.J., Harris, R.F., McSweeney, K., 1995. How farmers assess soil health and quality (Special Issue on Soil Quality). J. Soil Water Conserv. 50, 229-236.

Saunders, D.W., 1992. International activities in assessing and monitoring soil degradation (Special Issue on Soil Quality). Am. J. Alter. Agric. 7, 17-24.

Vitousek, P.M., Aber, J.D., Howarth, R.W., Likens, G.E., Matson, P.A., Schindler, D.W., Schlesinger, W.H., Tilman, D.G., 1997. Human alteration of the global nitrogen cycle: sources and consequences. Ecol. Appl. 7, 737-750.

Wolters, V., Schaefer, M., 1994. Effects of acid deposition on soil organisms and decomposition processes. In: Benckiser, G. (Ed.), Effects of Acid Rain on Forest Processes. Wiley, New York, pp. 83-127. 